\title{
EFEKTIVITAS PROGRAM PENINGKATAN PENGHIDUPAN MASYARAKAT BERBASIS KOMUNITAS (PPMK) DALAM MENINGKATKAN PENDAPATAN DI LEMBAGA KESW ADAYAAN MASYARAKAT (LKM) MARGODADI JAYA KOTA METRO
}

\author{
(Effectiveness of Increasing Income through Community-Based Livelihood Improvement Program (PPMK) \\ in Non-Governmental Organization (NGO) of Margodadi Jaya, Metro City) \\ Indah Ayu Dianti, Tubagus Hasanuddin, Begem Viantimala
}

Jurusan Agribisnis, Fakultas Pertanian, Universitas Lampung, Jl. Prof. Dr. Soemantri Brojonegoro No.1 Bandar Lampung 35141, Telp 085758884666, e-mail: indahayudianti @ gmail.com

\begin{abstract}
This study aims to find out the implementation of PPMK programme in Margodadi Subdistrict Metro City, to find out whether the PPMK programme has been effective in improving the income of KSM members in Metro City, and to find out the factors related to the effectiveness of PPMK Programme in Metro City. The location of this study was chosen purposively in Non-Governmental Organization (NGO) Margodadi Sub District, South Metro District, Metro City. The respondents of this research are 25 members of Kelompok Swadaya Masyarakat (KSM) who got capital loans in PPMK Programme. Data of this research was collected in August-September 2016. The research method used case method in which data was analyzed by descriptive and tabulation analysis to test the hypothesists. The results of the research showed that the implementation of PPMK Programme had been running well . PPMK Program was effective on improving the income of KSM members, and the factors that related to the effectiveness of PPMK Programme were human resource quality, sosial capital condition, and finance resource quality.
\end{abstract}

Key words: effectiveness, LKM, PPMK Programme.

\section{PENDAHULUAN}

Kehidupan perekonomian di Indonesia dari masa ke masa terus berjalan, namun perkembangan perekonomian yang terjadi dalam masyarakat cenderung tidak merata. Di satu sisi masyarakat dapat merasakan peningkatan pendapatan dalam kehidupan ekonominya, namun di sisi lain banyak masyarakat yang tidak mampu mengikuti perkembangan ekonomi yang ada. Hal ini dipicu oleh ketidakberdayaan masyarakat dalam menghadapi permasalahan ekonomi seperti lemahnya sektor usaha kecil dan menengah yang dijalankan dan kesulitan dalam hal permodalan.

Pada pembangunan ekonomi, kemiskinan merupakan masalah yang sering dihadapi oleh negara yang sedang berkembang tak terkecuali di Indonesia. Menurut Parsudi (1995), kemiskinan adalah suatu standar tingkat hidup yang rendah dengan adanya suatu tingkat kekurangan materi pada sejumlah atau segolongan orang dibandingkan dengan standar kehidupan yang umum yang berlaku dalam masyarakat yang bersangkutan.

Salah satu upaya Pemerintah dalam mengatasi kemiskinan yaitu mencanangkan Program Nasional
Pemberdayaan Masyarakat (PNPM) Mandiri, salah satunya adalah PNPM Mandiri Perkotaan. Terdapat 3 program yang dijalankan yaitu program pembangunan fisik, ekonomi, dan sosial. Salah satu bentuk program di bidang ekonomi yaitu berupa bantuan pinjaman ekonomi bergulir yang diberikan pada masyarakat miskin. Pinjaman bergulir diberikan untuk membantu kegiatan yang bersifat produktif dalam menciptakan peluang usaha dan kesempatan kerja untuk meningkatkan pendapatan masyarakat. Pemberian pinjaman diberikan langsung kepada masyarakat melalui Lembaga Keswadayaan Masyarakat (LKM) di masing-masing kelurahan di berbagai daerah tak terkecuali di Kota Metro, Provinsi Lampung.

LKM adalah suatu lembaga yang dibentuk guna memperlancar jalannya program PNPM-MP, lembaga inilah yang akan mengelola jalannya program (Kementerian Pekerjaan Umum 2007a). PPMK adalah program intervensi PNPM Mandiri Perkotaan yang diperuntukan bagi pengembangan kegiatan-kegiatan produktif yang sebelumnya telah meminjam dana ekonomi bergulir dengan tingkat pengembalian sebesar 98\%. Program PPMK bertujuan untuk menguatkan kelembagaan dan kegiatan usaha KSM secara mandiri dan berkesinambungan yang berorientasi pada 
peningkatan penghidupan masyarakat miskin (sustainable livelihood) dengan pendekatan pendampingan kelompok (Kementerian Pekerjaan Umum 2014). Kelompok Swadaya Masyarakat (KSM) adalah kumpulan orang yang menyatukan diri secara sukarela dalam kelompok dikarenakan adanya ikatan pemersatu yaitu visi, kepentingan dan kebutuhan yang sama, sehingga dalam kelompok tersebut memiliki kesamaan tujuan yang ingin dicapai bersama (Kementerian Pekerjaan Umum 2007b).

Namun, secara garis besar saat program PPMK ini telah berjalan di berbagai kota di Indonesia disinyalir memiliki berbagai masalah seperti keterlambatan dalam pembayaran angsuran pinjaman pada waktu yang telah ditentukan, dan tidak berdampak pada peningkatan pendapatan anggota KSM. Berdasarkan uraian tersebut, maka tujuan dari penelitian ini adalah mengetahui pelaksanaan program PPMK di Kelurahan Margodadi Kota Metro, mengetahui efektivitas program PPMK dalam meningkatkan pendapatan anggota KSM di Kota Metro dan mengetahui faktor-faktor yang berhubungan dengan efektivitas program PPMK di Kota Metro.

\section{METODE PENELITIAN}

Penelitian ini dilakukan di LKM Margodadi Jaya, Kelurahan Margodadi, Kota Metro. Lokasi penelitian dipilih secara sengaja (purposive) dengan pertimbangan LKM Margodadi Jaya adalah LKM terbaik se-Kota Metro yang mendapatkan program PPMK. Pengambilan data dilakukan pada bulan Agustus - September 2016. Responden penelitian ini didapat dari sampling jenuh yaitu penentuan sampel bila semua anggota populasi digunakan sebagai sampel, dengan istilah lain sensus (Sugiyono 2015). Responden adalah seluruh anggota KSM yang mengikuti program PPMK sebanyak 25 orang. Data yang digunakan dalam penelitian ini adalah data primer dan sekunder. Data primer diperoleh melalui proses wawancara serta pengamatan langsung pada anggota KSM dengan menggunakan kuesioner. Data sekunder diperoleh dari beberapa buku panduan teknis LKM, literatur dan sumber lain yang dapat dipercaya.

Jenis penelitian ini adalah deskriptif, analisis data dilakukan dengan menggunakan tabulasi silang. Tabulasi silang dibuat untuk melihat hubungan antar variabel terpengaruh dan pengaruh. Tabel disusun berdasarkan variabel yang mempunyai hubungan tertentu satu sama lain (Efendi dan Singarimbun 1989).

Pengukuran variabel $X$ pada penelitian ini menggunakan teknik skor dengan skor 1-3 dan diklasifikasikan ke dalam tiga kelas yaitu tinggi, sedang, rendah dan menggunakan bantuan program MSI (Method of Successive Interval). Variabel X1 kualitas sumberdaya manusia diukur dengan 4 indikator yaitu tingkat pendidikan, keterampilan, kemampuan membangun interaksi hubungan antar anggota, dan motivasi. Variabel X2 kondisi modal sosial, diukur menggunakan 3 indikator yaitu jaringan sosial, tingkat kepercayaan, serta peran dan dukungan stakeholder. Variabel X3 kualitas sumberdaya keuangan diukur menggunakan 2 indikator yaitu modal usaha yang dimiliki sebelum mengikuti program PPMK dibandingkan modal pinjaman pada program PPMK, serta sumber modal lain yang berupa pinjaman selain meminjam pada program PPMK.

Efektivitas program PPMK (variabel Y) dalam meningkatkan pendapatan anggota KSM dilihat dari pencapaian tujuan program tersebut yaitu peningkatan pendapatan anggota KSM yang diukur dengan menggunakan 2 indikator yaitu peningkatan pendapatan yang dirasakan anggota KSM, dan besarnya peningkatan pendapatan anggota KSM. Penguatan kapasitas kelembagaan KSM yang diukur dengan 6 indikator yaitu penggunaan modal pinjaman, cara mengangsur pinjaman, kesesuaian waktu pembayaran angsuran, pelaporan penggunaan dana pinjaman, kepemilikan sarana dan teknologi, penggunaan komputer dalam pengelolaan administrasi KSM, dan penggunaan internet dalam mengakses informasi dan perluasan kegiatan usaha KSM yang diukur dengan 2 indikator yaitu pertambahan jenis usaha anggota KSM dan pertambahan volume usaha anggota KSM.

\section{HASIL DAN PEMBAHASAN}

\section{Pelaksanaan Program PPMK}

Program PPMK di Kota Metro mulai dilaksanakan pada tanggal 6 Agustus 2014 di LKM Margodadi Jaya. Tahapan program terdiri dari tahap persiapan, perencanaan, pencairan dan pemanfaatan, serta tahap penguatan dan pengembangan. Sebelum program berjalan, LKM, KSM, serta para fasilitator kota melakukan pertemuan pada tahap persiapan program, dan dilanjutkan dengan pertemuan antar LKM dan KSM dengan jumlah pertemuan wajib sebanyak 8 
kali dari mulai tahap persiapan hingga pada tahap perencanaan.

\section{Tahapan Persiapan Program}

Pada tanggal 12-14 September 2014, LKM Margodadi Jaya melakukan seleksi KSM yang akan mendapatkan pinjaman sesuai dengan kriteria yang berlaku untuk program PPMK berdasarkan Kementerian Pekerjaan Umum 2014 yaitu satu atau dua di antara anggotanya masuk pada golongan masyarakat prasejahtera, memiliki kegiatan produktif yang berpotensi dikembangkan (prospektif), sebelumnya telah mengikuti program PNPM di bidang ekonomi yang bernama pinjaman ekonomi bergulir dengan tingkat pengembalian sebelumnya yaitu $100 \%$ dan, lancar membayar angsuran ekonomi bergulir minimal $95 \%$ tingkat ketepatan waktu pembayaran.

Berdasarkan hasil penelitian, maka kelompok KSM yang terpilih yaitu KSM Tunas Karya, Kenanga, Sembada, Kenari, dan Matahari dan masing-masing KSM terdiri dari 5 anggota. Berikutnya, LKM dan para fasilitator melakukan sosialisasi tentang pengenalan program PPMK kepada para anggota KSM di sekretariat LKM Margodadi Jaya.

\section{Tahapan perencanaan}

Pada tahap ini, pertemuan LKM dan KSM dilakukan selama 1 hari tiap satu minggu yang dimulai pada tanggal 5 September hingga 23 Oktober 2014. Perencanaan program dilakukan di masing-masing sekretariat KSM yang berada di rumah ketua anggota KSM. Tahap perencanaan program PPMK ini mencakup kegiatan pelatihanpelatihan yang membahas tentang mekanisme peminjaman dan penggunaan dana pinjaman dari program PPMK untuk mengembangkan usaha anggota KSM. KSM Sembada bergerak pada usaha pembenihan ikan patin, KSM Matahari bergerak pada usaha pembesaran ikan lele, pengolahan ikan, lele menjadi abon, kerupuk tulang ikan lele, dan disertai dengan usaha pemasarannya. KSM Kenari bergerak pada usaha aneka kue antara lain kue kering, kue basah, serta jajanan pasar.

KSM Tunas Karya bergerak pada usaha keripik yaitu keripik emping, keripik pisang, keripik singkong, dan berbagai keripik tergantung bahan baku yang tersedia dan KSM Kenanga bergerak pada usaha menjual sayuran mentah/ matang, aneka keripik, jajanan pasar, serta toko sembako.
Pelatihan ini dapat membantu KSM dalam mengajukan pinjaman program PPMK pada tahap selanjutnya yaitu tahap pencairan dan pemanfaatan pinjaman modal.

\section{Tahapan Pencairan dan Pemanfaatan Modal Pinjaman}

Dana yang diberikan oleh LKM ke KSM untuk program PPMK ini adalah sebesar Rp100.000.000,- yang diberikan dalam dua tahap pencairan. Total dana yang diberikan adalah Rp95.000.000,- karena Rp5.000.000,- digunakan untuk kegiatan selama persiapan sampai perencanaan program PPMK. Rangkaian kegiatan mulai dari pencairan pinjaman modal hingga pemanfaatannya terbagi menjadi 2 tahap. Tahap pertama pencairan dana sebesar 50\% yaitu Rp50.000.000,- dari pusat masuk pada rekening LKM. Tahap selanjutnya diberikan kepada 2 KSM Kelompok Usaha Bersama (KUBE). KSM KUBE terdiri dari KSM Sembada dan Matahari masingmasing memperoleh Rp25.000.000,- untuk mengembangkan usahanya.

Tahap kedua yaitu Enam bulan kemudian pencairan dilakukan, sebesar Rp45.000.000,- yang diberikan kepada masing-masing KSM sebesar Rp15.000.000,- yaitu KSM Kenanga, KSM Kenari, dan KSM Tunas Karya. Ketiga KSM ini adalah KSM yang memiliki usaha sejenis dan aneka usaha. Usaha aneka adalah usaha yang dijalankan oleh KSM Kenanga. Usaha sejenis adalah usaha yang dijalankan oleh KSM Kenari dan Tunas Karya. Selanjutnya, KSM dan LKM melakukan akad kredit yaitu peraturan pengembalian, cicilan, dan tanggungjawab KSM sesuai aturan yang ditentukan dan disepakati. KSM berkewajiban melakukan pengembalian pinjaman setiap bulannya dengan cara mengangsur sesuai dengan bunga yang telah disepakati yaitu sebesar 1,5\% per bulan. Secara keseluruhan, pelaksanaan program PPMK berjalan dengan lancar dan tidak ada kendala yang berarti yang terjadi saat tahaptahap pelaksanaan program PPMK. Hanya saja rentang waktu antara persiapan program hingga pencairan dana membutuhkan waktu yang cukup lama yaitu enam bulan sehingga anggota KSM harus menunggu cukup lama untuk mendapatkan pinjaman. Pada Tabel 1 dapat dilihat peningkatan pendapatan anggota KSM. 
Tabel 1. Peningkatan pendapatan anggota KSM

\begin{tabular}{cccc}
\hline $\begin{array}{c}\text { Selang } \\
\text { (skor) }\end{array}$ & Klasifikasi & $\begin{array}{c}\text { Jumlah } \\
\text { anggota } \\
\text { (orang) }\end{array}$ & Persentase \\
\hline $2,000-3,325$ & $\begin{array}{c}\text { Kurang } \\
\text { meningkat } \\
\text { Cukup }\end{array}$ & 6 & 24 \\
$3,326-4,651$ & $\begin{array}{c}\text { meningkat } \\
\text { Meningkat }\end{array}$ & 6 & 24 \\
$4,652-5,975$ & 4.560 & 25 & 52 \\
\hline Jumlah & Cukup meningkat & \\
\hline Rata - rata & &
\end{tabular}

\section{Deskripsi Variabel Y (Efektivitas Program PPMK)}

Efektivitas program PPMK adalah besarnya derajat keberhasilan dalam pencapaian tujuan program PPMK. Sesuai dengan kerangka pemikiran pada penelitian ini, pendapatan anggota KSM dilihat dari 3 indikator tujuan program yaitu peningkatan pendapatan anggota KSM, penguatan kapasitas kelembagaan KSM, dan perluasan kegiatan usaha anggota KSM.

\section{Peningkatan Pendapatan Anggota KSM}

Peningkatan pendapatan anggota KSM yaitu meningkatnya jumlah pendapatan yang diperoleh oleh anggota setelah mengikuti program PPMK. Sebaran peningkatan pendapatan anggota KSM setelah mengikuti program PPMK secara rinci dapat dilihat pada Tabel 1. Berdasarkan Tabel 1, peningkatan pendapatan anggota KSM sebanyak 13 orang (52\%) masuk pada klasifikasi meningkat, namun apabila dilihat dari nilai rata-rata skor peningkatan pendapatan yaitu 4,560 peningkatan pendapatan berada pada klasifikasi cukup meningkat (sedang). Penelitian ini sejalan dengan penelitian Aria (2016) yang menyatakan bahwa salah satu keberhasilan program PUAP dilihat pada outcome yang diperoleh (kemampuan yang baik dan pendapatan anggota gapoktan yang meningkat 50\%-70\% setelah mengikuti program PUAP).

Tabel 2. Penguatan kapasitas kelembagaan KSM

\begin{tabular}{cccc}
\hline $\begin{array}{c}\text { Selang } \\
\text { (skor) }\end{array}$ & Klasifikasi & $\begin{array}{c}\text { Jumlah } \\
\text { anggota } \\
\text { (orang) }\end{array}$ & Persentase \\
\hline $8,400-12,306$ & Kurang baik & 7 & 28 \\
$12,307-16,213$ & Cukup baik & 11 & 44 \\
$16,214-20,120$ & Baik & 7 & 28 \\
\hline Jumlah & 14.513 & 25 & 100 \\
\hline Rata - rata & Cukup baik & \\
\hline
\end{tabular}

\section{Penguatan Kapasitas Kelembagaan KSM}

Penguatan kapasitas kelembagaan KSM yaitu peningkatan kemampuan kelompok untuk memahami aturan dan melaksanakan pembangunan dalam arti luas secara berkelanjutan yang terdiri dari norma/ peraturan yang dijalankan serta sarana dan teknologi yang dimiliki anggota KSM. Tabel 2 berikut ini adalah sebaran penguatan kapasitas kelembagaan anggota KSM.

Berdasarkan Tabel 2, penguatan kapasitas kelembagaan anggota KSM 11 orang (44\%) masuk pada klasifikasi cukup baik dengan nilai rata-rata sebesar 14.513 .

\section{Kemampuan anggota KSM dalam Melakukan Perluasan Kegiatan Usaha}

Anggota KSM mampu melakukan perluasan kegiatan usaha yaitu tingkat kemampuan anggota KSM melakukan perluasan usaha. Hal ini dilihat dari pertambahan jenis usaha dan volume usaha. Sebaran tingkat kemampuan anggota KSM dalam melakukan perluasan kegiatan usaha dapat dilihat pada Tabel 3. Berdasarkan Tabel 3, tingkat kemampuan anggota KSM dalam melakukan perluasan kegiatan usaha sebanyak 9 orang $(68 \%)$ masuk dalam klasifikasi mampu, namun apabila dilihat dari nilai rata-rata yaitu 4,005 tingkat kemampuan anggota KSM masuk pada klasifikasi cukup mampu. Salah satu KSM memilih satu jenis usaha, KSM tersebut yaitu KSM Sembada dengan usaha pembenihan ikan patin. Pada pertambahan volume usahanya, anggota KSM Sembada mengalami peningkatan jumlah volume usaha. Hal ini menunjukkan bahwa meskipun jenis usaha hanya 1 jenis, tidak berpengaruh dengan pertambahan volume usahanya.

Berdasarkan penjelasan deskripsi efektivitas program PPMK di atas, dapat dilihat bahwa tujuan program tercapai dengan baik antara lain peningkatan pendapatan rumah tangga anggota KSM masuk pada klasifikasi meningkat, penguatan kapasitas kelembagaan KSM dengan klasifikasi cukup baik, serta kemampuan anggota KSM dalam memperluas usahanya pada klasifikasi mampu. Hal ini membuktikan bahwa program PPMK telah cukup efektif dalam meningkatkan pendapatan anggota KSM. 
Tabel 3. Kemampuan anggota KSM melakukan perluasan kegiatan usaha

\begin{tabular}{cccc}
\hline $\begin{array}{c}\text { Selang } \\
\text { (skor) }\end{array}$ & Klasifikasi & $\begin{array}{c}\text { Jumlah } \\
\text { anggota } \\
\text { (orang) }\end{array}$ & Persentase \\
\hline 2,000-3,255 & Kurang mampu & 8 & 32 \\
$3,256-4,511$ & Cukup mampu & 8 & 32 \\
4,512-5,767 & Mampu & 9 & 68 \\
\hline Jumlah & 4.005 & 25 & 100 \\
\hline Rata - rata & Cukup mampu \\
\hline
\end{tabular}

\section{Faktor-faktor yang berhubungan dengan Efektivitas Program PPMK dalam Meningkatkan Pendapatan Anggota KSM}

Pada penelitian ini faktor-faktor yang diduga berhubungan dengan efektivitas program PPMK dalam meningkatkan pendapatan anggota KSM adalah kualitas sumberdaya manusia (X1) yang meliputi tingkat pendidikan, keterampilan, kemampuan membangun interaksi hubungan antar anggota, dan motivasi. Kondisi modal sosial (X2) yang meliputi jaringan sosial, tingkat kepercayaan, serta peran atau dukungan stakeholder. Kualitas sumberdaya keuangan (X3) yang meliputi besarnya modal usaha sendiri dan pinjaman, serta sumber modal.

\section{Kualitas Sumberdaya Manusia (X1)}

Sumberdaya manusia adalah aset yang berkaitan dengan kemampuan seseorang untuk melakukan suatu aktivitas tertentu. Berdasarkan hasil penelitian yang dilakukan, kualitas sumberdaya manusia anggota KSM masuk pada klasifikasi sedang. Secara rinci kualitas sumberdaya manusia dapat dilihat pada Tabel 4, bahwa kualitas sumberdaya manusia berada pada klasifikasi tinggi yaitu 12 orang (48\%), namun apabila dilihat dari rata-ratanya kualitas sumberdaya manusia masuk pada klasifikasi sedang dengan nilai 15,195 . Hal ini menunjukkan bahwa kualitas sumberdaya manusia anggota KSM sudah cukup baik.

Tabel 4. Kualitas sumberdaya manusia KSM

\begin{tabular}{cccc}
\hline $\begin{array}{c}\text { Selang } \\
\text { (skor) }\end{array}$ & Klasifikasi & $\begin{array}{c}\text { Jumlah } \\
\text { anggota } \\
\text { (orang) }\end{array}$ & Persentase \\
\hline $9,792-13,222$ & Rendah & 7 & 28 \\
$13,223-16,653$ & Sedang & 6 & 24 \\
$16,654-20,082$ & Tinggi & 12 & 48 \\
\hline Jumlah & 15,195 & 25 & 100 \\
\hline Rata-rata & Sedang & & \\
\hline
\end{tabular}

Tabel 5. Kondisi modal sosial KSM

\begin{tabular}{cccc}
\hline $\begin{array}{c}\text { Selang } \\
\text { (skor) }\end{array}$ & Klasifikasi & $\begin{array}{c}\text { Jumlah } \\
\text { anggota } \\
\text { (orang) }\end{array}$ & Persentase \\
\hline $12,163-15,848$ & Rendah & 8 & 32 \\
$15,849-19,534$ & Sedang & 11 & 44 \\
$19,535-23,218$ & Tinggi & 6 & 24 \\
\hline Jumlah & 17,541 & 25 & 100 \\
\hline Rata-rata & Sedang & & \\
\hline
\end{tabular}

\section{Kondisi Modal Sosial (X2)}

Modal sosial adalah norma atau nilai yang telah dipahami bersama oleh masyarakat dalam rangka mencapai tujuan bersama. Berdasarkan hasil penelitian yang dilakukan, kondisi modal sosial anggota KSM masuk pada klasifikasi sedang sebanyak 11 orang $(44 \%)$ dengan nilai rata-rata 17,541. Secara rinci kondisi modal sosial dapat dilihat pada Tabel 5.

\section{Kualitas Sumberdaya Keuangan (X3)}

Sumberdaya keuangan adalah modal fisik yang dijadikan input dalam proses produksi yakni berupa uang (modal). Berdasarkan hasil penelitian yang dilakukan, kualitas sumberdaya keuangan anggota KSM masuk pada klasifikasi tinggi. Secara rinci kualitas sumberdaya keuangan dapat dilihat pada Tabel 6. Tabel 6 menunjukkan bahwa kualitas sumberdaya keuangan masuk pada klasifikasi tinggi dengan persentase sebanyak 11 orang (44\%) dengan rata-rata sebesar 4,633. Kualitas sumberdaya keuangan anggota KSM yang tinggi berdasarkan penelitian dikarenakan mayoritas anggota KSM tidak meminjam pinjaman modal lain selain pada program PPMK. Hal ini menunjukkan bahwa kualitas sumberdaya keuangan anggota KSM sudah cukup baik.

\section{Hubungan antara variabel $\mathrm{X}$ dan $\mathrm{Y}$}

Hubungan antara faktor-faktor yang berhubungan dengan efektivitas program PPMK dianalisis menggunakan tabulasi silang. Berdasarkan penelitian, faktor kualitas sumberdaya manusia (X1), kondisi modal sosial (X2), dan kualitas sumberdaya keuangan (X3) berhubungan positif dengan efektivitas program PPMK (Y). Pada tabel dijelaskan klasifikasi faktor-faktor yang berhubungan dengan efektivitas dikategorikan menjadi 3 kelas yaitu (R) adalah rendah, (S) sedang, dan (T) tinggi. Efektivitas program PPMK juga dikatergorikan menjadi 3 kelas yaitu (KE) kurang efektif, (CE) cukup efektif, (E) efektif, serta $\Sigma$ ialah jumlah anggota KSM. Secara rinci dapat dilihat pada Tabel 7, 8, dan 9 . 
Tabel 6. Kualitas sumberdaya keuangan KSM

\begin{tabular}{cccc}
\hline $\begin{array}{c}\text { Selang } \\
\text { (skor) }\end{array}$ & Klasifikasi & $\begin{array}{c}\text { Jumlah } \\
\text { anggota } \\
\text { (orang) }\end{array}$ & Persentase \\
\hline $2,000-3,307$ & Rendah & 6 & 24 \\
$3,308-4,615$ & Sedang & 8 & 32 \\
$4,616-5,921$ & Tinggi & 11 & 44 \\
\hline Jumlah & 4,633 & 25 & 100 \\
\hline Rata-rata & Tinggi & & \\
\hline
\end{tabular}

Tabel 7. Tabulasi hubungan antara X1 dan Y

\begin{tabular}{cccccc}
\hline $\mathrm{X} 1$ & $\mathrm{Y}$ & $\mathrm{KE}$ & $\mathrm{CE}$ & $\mathrm{E}$ & $\Sigma$ \\
\hline $\mathrm{R}$ & 7 & 3 & 4 & 0 & 7 \\
$\mathrm{~S}$ & 6 & 3 & 2 & 1 & 6 \\
$\mathrm{~T}$ & 12 & 3 & 3 & 6 & 12 \\
\hline$\Sigma$ & 25 & & & & 25 \\
\hline
\end{tabular}

\section{Hubungan antara Kualitas Sumberdaya Manusia dengan Efektivitas Program PPMK dalam Meningkatkan Pendapatan Anggota KSM}

Sumberdaya manusia (SDM) adalah salah satu faktor yang sangat penting bahkan tidak dapat dilepaskan dari sebuah organisasi, baik institusi maupun perusahaan. Pada penelitian ini, indikator kualitas sumberdaya manusia yaitu tingkat pengetahuan anggota KSM, tingkat keterampilan anggota KSM, tingkat kemampuan, dan tingkat motivasi. Berdasarkan penelitian dan analisis tabulasi yang telah dilakukan, dapat dilihat pada Tabel 7, kualitas sumberdaya manusia anggota KSM yang berada pada klasifikasi rendah, sebanyak $28 \%$ cenderung kurang berdampak pada efektivitas program sebesar $12 \%$. Anggota KSM yang berada pada klasifikasi sedang sebanyak $24 \%$ orang cenderung cukup efektif terhadap program PPMK sebesar $12 \%$, sedangkan anggota yang berada pada klasifikasi tinggi sebanyak $44 \%$ orang cenderung efektif terhadap program sebesar $20 \%$. Hal ini berarti bahwa kualitas sumberdaya manusia berhubungan positif dengan efektivitas program PPMK dalam meningkatkan pendapatan anggota KSM pada klasifikasi tinggi. Tabel 7 menunjukkan semakin tinggi kualitas sumberdaya manusia yang dimiliki oleh anggota KSM, maka program PPMK juga akan semakin efektif dalam mencapai tujuan yang telah ditetapkan yaitu peningkatan pendapatan anggota KSM. Hasil penelitian ini sejalan dengan penelitian yang dilakukan oleh Sari (2011) bahwa faktor-faktor yang berpengaruh nyata dengan efektivitas program pemberdayaan ekonomi masyarakat yaitu meliputi tingkat pendidikan formal dan tingkat keterampilan. Penelitian Mutakin (2013) yang menyatakan bahwa salah satu faktor yang berhubungan dengan efektivitas program PNPMMP adalah tingkat pengetahuan anggota kelompok. Penelitian Praja (2015) bahwa pendidikan formal penyuluh memiliki hubungan yang nyata terhadap kinerja penyuluh di BP3K Kecamatan Batanghari dan meningkatnya pendapatan penyuluh di masing-masing wilayah kerja.

\section{Hubungan antara Kondisi Modal Sosial dengan Efektivitas Program PPMK dalam Meningkatkan Pendapatan Anggota KSM}

Modal sosial adalah modal berupa norma atau nilai yang telah dipahami bersama oleh masyarakat dalam rangka mencapai tujuan bersama. Pada penelitian ini kondisi modal sosial meliputi banyaknya jaringan sosial, tingkat kepercayaan, serta peran dan dukungan stakeholder dalam kaitannya pada program PPMK. Berdasarkan penelitian dan analisis tabulasi yang telah dilakukan, dapat dilihat pada Tabel 8, kondisi modal sosial anggota KSM yang berada pada klasifikasi rendah, sebanyak $32 \%$ cenderung kurang berdampak pada efektivitas program sebesar 20\%. Anggota KSM yang berada pada klasifikasi sedang sebanyak $44 \%$ orang cenderung cukup efektif terhadap program PPMK sebesar $20 \%$, sedangkan anggota yang berada pada klasifikasi tinggi sebanyak $24 \%$ orang cenderung efektif terhadap program sebesar $12 \%$.

Hal ini berarti bahwa kondisi modal sosial berhubungan cukup positif dengan efektivitas program PPMK dalam meningkatkan pendapatan anggota KSM pada klasifikasi sedang. Tabel 8 menunjukkan semakin tinggi dan baik kondisi modal sosial yang dimiliki oleh anggota KSM, maka program PPMK juga akan berjalan dengan efektif dalam mencapai tujuan yang telah ditetapkan yaitu meningkatkan pendapatan anggota KSM. Penelitian ini sejalan dengan hasil penelitian Kholifa (2016) bahwa pengaruh modal sosial yang berhubungan nyata terhadap produktivitas dan peningkatan pendapatan petani di antaranya kepercayaan, jaringan, dan norma sosial.

Tabel 8. Tabulasi hubungan antara X2 dan Y

\begin{tabular}{cccccc}
\hline $\mathrm{X} 2$ & $\mathrm{Y}$ & $\mathrm{KE}$ & $\mathrm{CE}$ & $\mathrm{E}$ & $\Sigma$ \\
\hline $\mathrm{R}$ & 8 & 5 & 3 & 0 & 8 \\
$\mathrm{~S}$ & 11 & 2 & 5 & 4 & 11 \\
$\mathrm{~T}$ & 6 & 2 & 1 & 3 & 6 \\
\hline$\Sigma$ & 25 & & & & 25 \\
\hline
\end{tabular}


Tabel 9. Tabulasi hubungan $\mathrm{X} 3$ dan $\mathrm{Y}$

\begin{tabular}{|c|c|c|c|c|c|}
\hline X3 & Y & KE & CE & $\mathrm{E}$ & $\Sigma$ \\
\hline $\mathrm{R}$ & 6 & 4 & 2 & 0 & 6 \\
\hline$S$ & 8 & 4 & 2 & 2 & 8 \\
\hline $\mathrm{T}$ & 11 & 1 & 5 & 5 & 11 \\
\hline$\Sigma$ & 25 & & & & 25 \\
\hline
\end{tabular}

Hubungan antara Kualitas Sumberdaya Keuangan dengan Efektivitas Program PPMK dalam Meningkatkan Pendapatan Anggota KSM

Kualitas sumberdaya keuangan pada penelitian ini meliputi modal usaha yang dimiliki sebelum mengikuti program PPMK dibandingkan modal pinjaman pada program PPMK dan sumber pinjaman lain yang dimiliki anggota KSM selain pada program PPMK. Berdasarkan hasil penelitian dan analisis tabulasi yang dilakukan, dapat dilihat pada Tabel 9 bahwa kualitas sumberdaya keuangan anggota KSM yang berada pada klasifikasi rendah, sebanyak $24 \%$ cenderung kurang berdampak pada efektivitas program sebesar $16 \%$. Anggota KSM yang berada pada klasifikasi sedang sebanyak 32\% orang cenderung cukup efektif terhadap program PPMK sebesar $8 \%$, sedangkan anggota yang berada pada klasifikasi tinggi sebanyak $44 \%$ orang cenderung efektif terhadap program sebesar $20 \%$.

Hal ini berarti bahwa kualitas sumberdaya keuangan berhubungan positif dengan efektivitas program PPMK dalam meningkatkan pendapatan anggota KSM pada klasifikasi tinggi. Tabel 9 menunjukkan bahwa semakin tinggi dan baik kualitas sumberdaya keuangan anggota KSM, semakin efektif pula program PPMK dalam meningkatkan pendapatan anggota KSM. Hasil penelitian ini sejalan dengan penelitian Aquino (2010) bahwa salah satu faktor yang berhubungan dengan tingkat efektivitas program yaitu dana PNPM-MP.

\section{KESIMPULAN}

Berdasarkan hasil penelitian disimpulkan bahwa pelaksanaan program PPMK pada LKM Margodadi Jaya meliputi tahap persiapan program, tahap perencanaan program, tahap pelaksanaan program, serta tahap penguatan program telah berjalan dengan baik. Efektivitas program PPMK dalam meningkatkan pendapatan anggota KSM dinyatakan telah berjalan efektif, hal ini dilihat dari pencapaian tujuan program PPMK yaitu peningkatan pendapatan anggota KSM, penguatan kapasitas kelembagaan KSM, serta kemampuan anggota KSM dalam perluasan kegiatan usaha. Faktor-faktor yang berhubungan positif dengan efektivitas program PPMK antara lain yaitu kualitas sumberdaya manusia anggota KSM, kondisi modal sosial, serta kualitas sumberdaya keuangan.

\section{DAFTAR PUSTAKA}

Aquino H. 2010. Efektivitas Program Nasional Pemberdayaan Masyarakat Mandiri Pedesaan (PNPM-MP) dalam memberdayakan masyarakat pedesaan di Kecamatan Negeri Katon Kabupaten Pesawaran Provinsi Lampung. Skripsi. Universitas Lampung. Bandar Lampung.

Aria RA. 2016. Peranan Penyuluh Pertanian Lapangan (PPL) terhadap Keberhasilan Program Pengembangan Usaha Agribisnis Pedesaan (PUAP) di Kecamatan Sungkai Selatan, Kabupaten Lampung Utara. JIIA, 4 (4):430-436. http://jurnal.fp.unila.ac.id /index.php/JIA/article/view/1526/1380.

[2 Juni 2017].

Efendi S dan Singarimbun M. 1989. Metode Penelitian Survai. LP3ES. Jakarta.

Kementerian Pekerjaan Umum. 2007a. Modul petujuk teknis pembangunan LKM. Direktorat jenderal cipta karya. Jakarta. http://www.p2kp.org/pustaka/files/modul_ pelatihan8/A/6/Buku5PembangunanBKM. pdf. Diakses pada tanggal 1 Januari 2016. . 2007b. Modul petunjuk teknis pelaksanaan KSM. Direktorat jenderal cipta karya. Jakarta. http://www.p2kp.org/pustaka/files/modul_ petunjuk_teknis_KSM.pdf. Diakses pada tanggal 1 Januari 2016.

. 2014. Modul

petujuk teknis pelaksanaan PPMK. Direktorat jendral cipta karya. Jakarta. http://www.p2kp.org/pustaka/files/lo_ped oman_teknis_ppmk_rev_final.pdf. Diakses pada tanggal 1 Januari. 2016.

Kholifa N. 2016. Pengaruh modal sosial terhadap produktivitas petani (Studi kasus di Kecamatan Cilacap Utara Kabupaten Cilacap). Jurnal Pendidikan dan Ekonomi.

5, (2): 89-97. http://journal.student.uny.ac.id /ojs/index.php/ekonomi/article/view/3984/364 1. [ 2 Januari 2017].

Mutakin. 2013. Efektivitas Program Nasional Pemberdayaan Masyarakat Mandiri Pedesaan (PNPM-MP) di Kecamatan Ngambur 
Kabupaten Lampung Barat. JIIA, 1 (2): 134139. http://jurnal.fp.unila.ac.id/index.php/JIA /article/view/240/239. [26 November 2016].

Parsudi S. 1995. Kemiskinan di Perkotaan. Yayasan Obor Indonesia. Jakarta.

Praja FB. 2015. Efektivitas Program Pengembangan BP3K Sebagai Model Center Of Excelence $(\mathrm{CoE})$ dalam peningkatan kinerja penyuluh di Kecamatan Batanghari Kabupaten Lampung Timur. JIIA, 3 (2): 179186. http://jurnal.fp.unila.ac.id/index .php/JIA /article/view/1037/942. [2 Juni 2017].

Saputra H. 2016. Keefektifan Program Gerakan Serentak Membangun Kampung (GSMK) dalam memberdayakan masyarakat pedesaan di Kecamatan Rawa Pitu Kabupaten Tulang Bawang. JIIA, 4 (1):104-110.http://jurnal .fp.unila.ac.id/index.php/JIA/article/view/122 0/1117http://jurnal. [2 Juni 2017].

Sari N. 2011. Efektivitas pemberdayaan ekonomi masyarakat pembudidaya ikan air tawar di kawasan pesisir Desa Margasari Kecamatan Labuhan Maringgai Kabupaten Lampung Timur. Skripsi. Universitas lampung. Bandar lampung.

Sugiyono. 2015. Metode Penelitian Kuantitatif, Kualitatif, dan $R \& D$. Cetakan ke 22. Alfabeta. Bandung. 